原 著

\title{
アミオダロン静脈注射薬がBrugada症候群患者における 心室紼動誘発に与える影響
}

北條林太郎 ${ }^{1}$ 辰本明子 ${ }^{1}$ 高野 誠 $^{1}$ 仲井 盛 $^{1}$

小田切史德 ${ }^{1}$ 小宮山浩大 ${ }^{1}$ 弓場隆生 $^{1}$ 大塚信一郎 $^{1}$

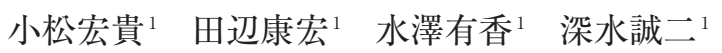

手島 保 ${ }^{1}$ 櫻田春水 ${ }^{1 *}$ 西崎光弘 ${ }^{2}$ 平岡昌和 ${ }^{3}$

【背景】心室細動(VF)，心室頻拍に対するアミオダロン(AMD) 静注薬は 2007 年より本邦でも使用 可能になつた. しかし, Brugada 症候群におけるVFに対する AMD 静注薬の有効性に一定の見解 は得られていない.【目的】Brugada症候群におけるVFの誘発性に対しAMD 静注薬の及ぼす影響 を, 電気生理学的検査 (EPS) を用いて検討した.【対象・方法】無投薬もしくはピルジカイニド負 荷試験にて type 1 Brugada 型心電図を呈し，心事故の危険性を層別化するために行つた EPS に よりVFが誘発された連続 7 例を対象とした，全例男性で，失神歴を有する 1 例を除き無症候性で あつた. これらに対して AMD 静注薬を投与し, 投与前後での電気生理学的特徵, VF の誘発性を 比較した.【結果】AMD 静注射後にEPS を施行したところ, AH 間隔(投与前 $97.9 \pm 12.2 \mathrm{msec}$, 投与後 $118.6 \pm 16.1 \mathrm{msec} p$ 值 $=0.0008$ ) と HV 間隔 (投与前 $47.1 \pm 7.6 \mathrm{msec}$ ，投与後 $53.7 \pm 8.9 \mathrm{msec} p$ 值 $=0.012)$ の延長を認めた. 7 例中 5 例は，無投薬下でVF 誘発のために 右室心尖部もしくは右室流出路の 3 連期外刺激を要したが, AMD 静注薬投与後はより簡易な 2 連 期外刺激でVFが誘発された。【結論】Brugada 症候群におけるVFの誘発性はAMD 静注薬では抑 制されなかつた.

(心電図, $2010 ； 30 ： 123$ ～130)

\begin{tabular}{|c|c|}
\hline Keywords & $\begin{array}{l}\text { - Brugada症候群 } \\
\text { •アミオダロン } \\
\text { - 電気生理学的検査 }\end{array}$ \\
\hline
\end{tabular}

1 東京都立広尾病院循環器科

（１50-0013＼cjkstart東京都渋谷区恵比寿 2-34-10）

2 横浜南共済病院循環器科

3 東京医科歯科大学

*は責任著者を示す (所属は著者に同じ)

\section{I 、はじめに}

心肺蘇生の現場でアミオダロン (AMD) 静注薬の 有用性が報告されている ${ }^{1), 22}$ 。本邦でも2007年 6 月 に AMD 静注薬が認可され, 臨床の場で用いられる ようになった。そのため, 救急の現場において心室 細動 $(\mathrm{VF})$ を合併したBrugada症候群患者に対して

Effect of Intravenous Amiodarone on inducibility of Ventricular Fibrillation in patients with Brugada syndrome Rintaro Hojo, Akiko Tatsumoto, Makoto Takano, Mori Nakai, Fuminori Odagiri, Kouta Komiyama, Takao Yuba, Shinichiro Otuka, Hirotaka Komatsu, Yasuhiro Tanabe, Yuka Mizusawa, Seiji Fukamizu, Tamotsu Tejima, Harumizu Sakurada, Mitsuhiro Nishizaki, Masayasu Hiraoka

2009 年 10 月 28 日 原稿受領 $/ 2010$ 年 3 月 23 日 掲載承認 
も AMDが静脈投与される可能性がある。しかしな がら，AMD 内服薬は有症候性 Brugada症候群にお けるVFの抑制には無効であったという報告も存在 し ${ }^{3)}$, 4), Brugada 症候群に対するAMDの効果は疑問 視されている. AMD 静注薬についても一定の見解 は得られておらず，Brugada症候群患者における electorical stormに有効であったという報告がみら れる ${ }^{5)}$ 一方，AMDの静脈投与により Brugada型心電 図が顕在化したとの症例報告もみられる ${ }^{6)}$.

$\mathrm{AMD}$ 静注薬は急性期においては $\mathrm{Na}^{+}$チャネル抑 制作用が強く，また，一過性外向き電流 $\left(\mathrm{I}_{\mathrm{to}}\right)$ 抑制作 用を有さないなど AMD 内服中の慢性期とは異なる $\mathrm{K}^{+}$チャネル抑制作用がある。しかし，これらの特徵 がBrugada症候群に及ぼす影響は明らかではない7)。

今回われわれは, Brugada症候群に対する AMD 静注薬の影響を, 電気生理学的検査 $(\mathrm{EPS})$ を用いて 検討した。

\section{II . 対象と方法}

\section{1. 対象}

無投薬もしくはピルジカイニド負荷試験 $(1 \mathrm{mg} / \mathrm{kg} / 10$ 分) で正常肋間あるいは $1 \sim 2$ 肋間上の 右側胸部誘導心電図はtype 1 Brugada型心電図を呈 し，心事故の危険性を層別化するために行った EPS により，VFが誘発された 7 例を対象とした(表1). 心臓超音波検査にて器質的心疾患の有無および左室 駆出率 (ejection fraction：EF) を確認した。全例で Corazonics 社製Predictor Unit Version 6.1を用い て加算平均心電図 ( signal average electrocardiogram：SAECG) を測定し, (1) fQRS > $114 \mathrm{msec}$, (2) RMS40 $<20 \mathrm{uV}$, (3)LAS40 $>38 \mathrm{msec}$ の 3 項目のうち 2 項目以上を満たすものを陽性と した。

\section{2. 心臓カテーテル検査・電気生理学的検査}

EPSに先立ち，本人および家族に説明を行い，文 書による同意を得た。

プロポフォール $(3 \sim 5 \mathrm{mg} / \mathrm{kg} /$ 時 $)$ による静脈麻酔 で鎮静させた後，検査を行った。全例冠動脈造影検
査にて冠動脈疾患がないことを確認したうえで, EPSを行った。刺激出力は拡張期閾值の 2 倍に設定 した.

無投薬下に AA 間隔 $(\mathrm{msec}), \mathrm{AH}$ 間隔 $(\mathrm{msec})$, HV 間隔 (msec), QRS幅 (msec), QTc 時間 $(\mathrm{msec})$, 基本刺激間隔 $400 \mathrm{msec}$ での右室心尖部 (right ventricular apex : RVA), 右室流出路 (right ventricular outflow tract：RVOT), 高位右房 (high right atrium：HRA)における有効不応期 (effective refractory period：ERP)を測定した。心室での期 外刺激はRVAおよびRVOTの 2 力所から 3 連期外刺 激まで, 基本刺激周期は $600 \mathrm{msec}$ と $400 \mathrm{msec} の 2$ 種 類で行った。

最短刺激周期は 2 連期外刺激では $180 \mathrm{msec}, 3$ 連

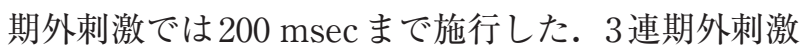
では，その範囲内で心室筋を捕捉可能な最短刺激周 期にて 5 回繰り返した。頻回刺激は刺激頻度 200 拍/ 分から 250 拍/分の間で 10 拍/分ごとに刺激頻度を早 めて施行し，各周期の刺激数は $10 〜 20$ 拍とした。

RVA からの単発期外刺激, 2 連期外刺激, 3 連期 外刺激を行った後に頻回刺激を施行し, その後, 同 様のプロトコールにてRVOTからの刺激を施行 した。

直流電流による停止が必要なVFが同様の心室プ ログラム刺激にて再現性をもって誘発された場合， $\mathrm{VF}$ 誘発ありと判断した.

$\mathrm{AMD}$ 静注薬投与後に同様のプロトコールにて EPS を行った。なお，AMD静注薬投与後は，すべての 刺激プロトコールを終了するか，あるいは誘発性が 不変もしくは悪化を確認した時点で刺激を終了し た.この際にも VF誘発性の再現性を確認した.

\section{3. アミオダロンの投与方法}

本邦で推奨されている $\mathrm{AMD}$ 静注薬の投与方法に 従い, AMD $125 \mathrm{mg}$ を $5 \%$ ブドウ糖液 $100 \mathrm{ml}$ に溶解し たものを 10 分間かけて投与した後に血中濃度を測定 し，引き続き AMD $150 \mathrm{mg}$ を $5 \%$ ブドウ糖液 $100 \mathrm{ml}$ に溶解したものを $33 \mathrm{ml} /$ 時間で投与を開始した。持 続静脈注射開始直後より EPSを施行した。 


\section{表 1 対象患者背景}

\begin{tabular}{|c|c|c|c|c|c|c|c|c|}
\hline & 性別 & 年齢 & 家族歴 & 失神歴 & 心電| & & $\begin{array}{c}\text { SAECG } \\
\text { (RMS40) } \\
\text { (LAS40) } \\
\text { (fQRS) }\end{array}$ & $\mathrm{EF}$ \\
\hline 症例 (1) & 男性 & 41歳 & $(-)$ & $(-)$ & $\begin{array}{l}\text { Control } \\
\text { Pilsicainide }\end{array}$ & $\begin{array}{l}\Rightarrow \text { type } 1 \\
\Rightarrow \text { 未施行 }\end{array}$ & $\begin{array}{c}13.85 \mathrm{uV} \\
47.5 \mathrm{msec} \\
134 \mathrm{msec}\end{array}$ & $61 \%$ \\
\hline 症例(2) & 男性 & 38歳 & $\begin{array}{c}\text { 兄 : 突然死 } \\
\text { 甥 : Brugade } \\
\text { ECG }\end{array}$ & $(-)$ & $\begin{array}{l}\text { Control } \\
\text { Pilsicainide }\end{array}$ & $\begin{array}{l}\Rightarrow \text { type } 2 \\
\Rightarrow \text { type } 1\end{array}$ & $\begin{array}{c}10.24 \mathrm{uV} \\
62 \mathrm{msec} \\
128 \mathrm{msec}\end{array}$ & $64 \%$ \\
\hline 症例 (3) & 男性 & 26歳 & $(-)$ & $(-)$ & $\begin{array}{l}\text { Control } \\
\text { Pilsicainide }\end{array}$ & $\begin{array}{l}\Rightarrow \text { type } 3 \\
\Rightarrow \text { type } 1\end{array}$ & $\begin{array}{c}16.45 \mathrm{uV} \\
55 \mathrm{msec} \\
118 \mathrm{msec}\end{array}$ & $65 \%$ \\
\hline 症例(4) & 男性 & 54歳 & $(-)$ & $(-)$ & $\begin{array}{l}\text { Control } \\
\text { Pilsicainide }\end{array}$ & $\begin{array}{l}\Rightarrow \text { type } 1 \\
\Rightarrow \text { 未施行 }\end{array}$ & $\begin{array}{c}6.43 \mathrm{uV} \\
62 \mathrm{msec} \\
123 \mathrm{msec}\end{array}$ & $71 \%$ \\
\hline 症例(5) & 男性 & 62歳 & $(-)$ & $(-)$ & $\begin{array}{l}\text { Control } \\
\text { Pilsicainide }\end{array}$ & $\begin{array}{l}\Rightarrow \text { type } 2 \\
\Rightarrow \text { type } 1\end{array}$ & $\begin{array}{c}28.65 \mathrm{uV} \\
34 \mathrm{msec} \\
135 \mathrm{msec}\end{array}$ & $61 \%$ \\
\hline 症例 (6) & 男性 & 72歳 & $(-)$ & $(+)$ & $\begin{array}{l}\text { Control } \\
\text { Pilsicainide }\end{array}$ & $\begin{array}{l}\Rightarrow \text { type } 1 \\
\Rightarrow \text { type } 1\end{array}$ & $\begin{array}{c}16.04 \mathrm{uV} \\
39.0 \mathrm{msec} \\
113 \mathrm{msec}\end{array}$ & $60 \%$ \\
\hline 症例 (7) & 男性 & 40歳 & $(-)$ & $(-)$ & $\begin{array}{l}\text { Control } \\
\text { Pilsicainide }\end{array}$ & $\begin{array}{l}\Rightarrow \text { type } 1 \\
\Rightarrow \text { type } 1\end{array}$ & $\begin{array}{c}15.2 \mathrm{uV} \\
34.5 \mathrm{msec} \\
122 \mathrm{msec}\end{array}$ & $79 \%$ \\
\hline
\end{tabular}

アミオダロン静注薬投与後は, 誘発性が不変もしくは悪化が確認できた時点で刺激 を終了している. そのため, 斜線の個所は刺激を施行していない. 全例, 心室細動 が誘発された刺激様式で誘発の再現性をみているが，誘発されなければほかの部位 からの同様の刺激様式でみられた場合再現性ありと判断している(症例 $5,6,7$ ). 症 例 1 のアアオダロン静注薬投与後の刺激を右室流出路(RVOT)から開始したため, 右室心尖部 (RVA) からの刺激は施行されていない. 7 例中 5 例でアミオダロン静注 薬投与前には 3 連期外刺激のみで心室細動が誘発されたものが，アミオダロン静注 薬投与後にはより簡易な 2 連刺激にて心室細動が誘発されるようになった.

\section{4. 評価項目}

$\mathrm{AMD}$ 静注薬投与前後で，電気生理学的指標，体表 面 12 誘導心電戝所見およびVFの誘発性を評価した。

電気生理学的指標に関しては投与前後で対応す る $t$ 検定を用いて評価し, $\mathrm{p}<0.05$ を有意差ありと 判断した.

\section{III. 結果}

対象は全例男性で，年齢は $46.6 \pm 5.3$ 歳であった。 失神歴，突然死の家族歴を有しているものはそれぞ れ1例であった。 4例は無投薬下にて type 1 Brugada 型心電図を呈し，ほかの3 例ではピルジカイニド負
荷試験にて type 1 Brugada型心電図へと変化した. 心臓超音波検査では器質的心疾患を有した症例はな く, EFは正常であった。6例で心室遅延電位は陽性 であった。

EPS 開始時の AMD 血中濃度は 4,976 $\pm 716 \mathrm{pg} / \mathrm{ml}$ $(1,813 \sim 8,097 \mathrm{pg} / \mathrm{ml})$ であり, 全例有効血中濃度域 に達していた。

\section{1. 電気生理学的指標の变化}

$\mathrm{AH}$ 間隔 (投与前 $97.9 \pm 12.2 \mathrm{msec}$ ，投与後 $118.6 \pm$ $16.1 \mathrm{msec} p$ 值 $=0.0008)$, HV 間隔 (投与前 $47.1 \pm$ $7.6 \mathrm{msec}$ ，投与後 $53.7 \pm 8.9 \mathrm{msec} \mathrm{p}$ 值 $=0.012)$ は $\mathrm{AMD}$ 静注薬投与後有意に延長した。 $\mathrm{AA}$ 間隔 (投与 


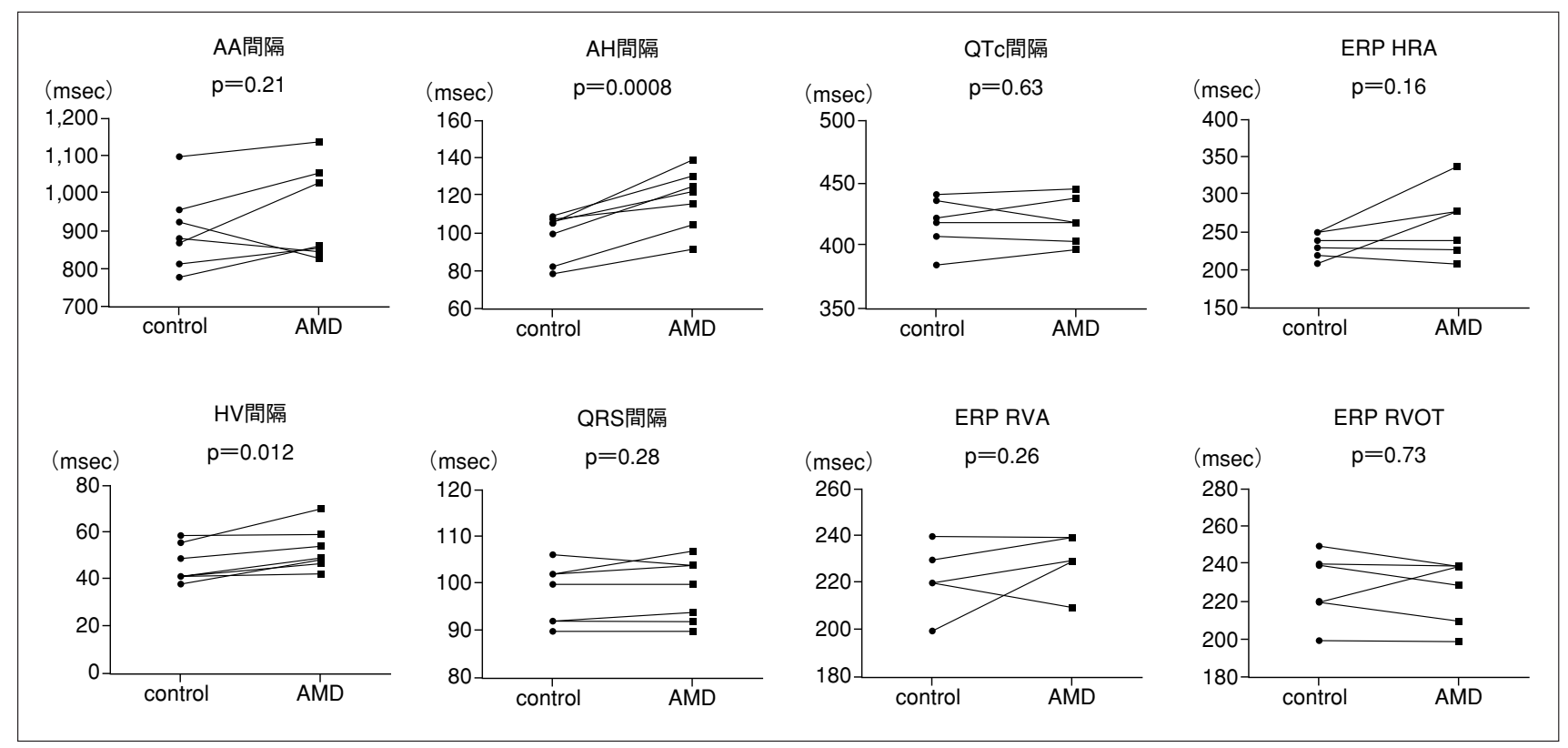

図1 電気生理学的検査

$\mathrm{AH}$ 間隔，HV 間隔は有意差をもって延長が認められている。アアオダロン静注薬投与後に症例 1 では右室心尖部 (RVA)の, 症例 4 では右室流出路 (RVOT)の有効不応期 (ERP) を測定していない(表2 参照).

前 $902.0 \pm 105.3 \mathrm{msec}$ ，投与後 $947.0 \pm 125.1 \mathrm{msec} p$ 值 $=0.21 ）$ は延長傾向であったが，有意差は認められ

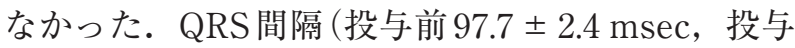
後 $98.7 \pm 2.5 \mathrm{msec}$ p 值 $=0.28)$ QTc 間隔 $($ 投与前 $421.1 \mathrm{msec} \pm 7.1 \mathrm{msec}$, 投与後 $424.0 \mathrm{msec} \pm$ $6.9 \mathrm{msec} \mathrm{p}$ 值 = 0.63)には，明らかな変化はみられ なかった(図1).

\section{2. 心室・心房における有効不応期の変化}

$\mathrm{RVA}$ (投与前 $221.7 \pm 5.4 \mathrm{msec}$ 投与後 $230.0 \pm$ $4.5 \mathrm{msec} p$ 值 $=0.26$ ), $\operatorname{RVOT}($ 投与前 $224.3 \pm$ $7.5 \mathrm{msec}$ ，投与後 $222.9 \pm 7.1 \mathrm{msec} \mathrm{p}$ 值 $=0.73)$ ， $\mathrm{HRA}$ (投与前 $233.3 \pm 6.7 \mathrm{msec}$ ，投与後 $263.3 \pm$ $19.1 \mathrm{msec} \mathrm{p}$ 值 $=0.14)$ の ERPには，有意な変化はみ られなかった(図1).

\section{3. 体表面心電図の変化}

EPS 開始時には type 1 Brugada型心電図が2例, type 2 Brugada型心電図が 3 例，正常心電図が 2 例 であった。

症例 3 の正常肋間心電図では無投薬下にて type 3 Brugada型心電図であったものが，AMD 静注薬投 126
与により type 2 Brugada型心電図に変化している. その他の症例では明らかな心電図変化は認められな かった(図2).

\section{4. 心室細動の誘発性の変化}

7 例中 5 例 (症例 $1 ， 2 ， 5 ， 6 ， 7$ ) は, AMD 静注薬 投与前では 3 連期外刺激によってのみ VFが誘発さ れたが， $\mathrm{AMD}$ 静注薬投与後にはより簡易な 2 連期 外刺激にてVFが誘発されるようになった。また， 1 例 (症例 4)では投与前に誘発されなかったRVAから のプログラム刺激によるVFの誘発が可能となった。

なお，誘発されたすべてのVFは 2 相性 $150 \mathrm{~J}$ の通 電にて除細動が可能であった(表2).

\section{IV. 考察}

\section{1. 電気生理学的指標の変化}

これまでに報告された $\mathrm{AMD}$ 静注・経口投与前後 の電気生理学的特徵 $\left.{ }^{8}, 9\right)$ と, 今回の結果を比較した.

以前の報告によると静脈投与では $\mathrm{AH}$ 間隔と房室 結節の ERP を延長させる効果がみられ，経口薬の慢 性的な投与ではそれに加え QTcの延長，心拍数の低 


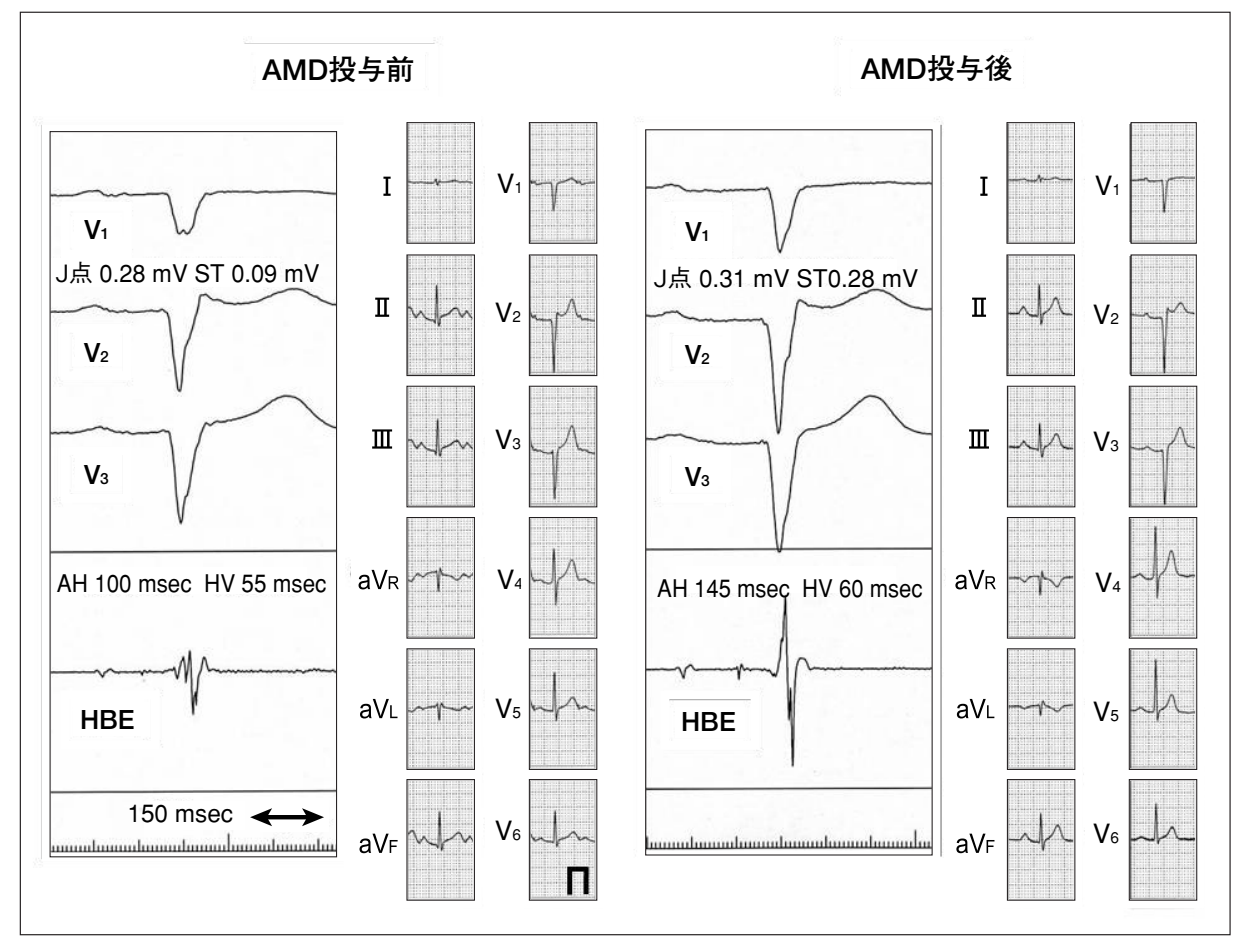

図2 体表面心電図

症例 3 の正常肋間心電図では無投薬下にて type 3 Brugada型心電図であったものが，アミオ ダロン静注薬投与により type 2 Brugada型心電図に変化している.

\section{表2 心室細動誘発性}

\begin{tabular}{|c|c|c|c|c|c|c|c|c|c|c|c|c|c|c|}
\hline & \multicolumn{2}{|c|}{ 症例 (1) } & \multicolumn{2}{|c|}{ 症例(2) } & \multicolumn{2}{|c|}{ 症例 (3) } & \multicolumn{2}{|c|}{ 症例(4) } & \multicolumn{2}{|c|}{ 症例(5) } & \multicolumn{2}{|c|}{ 症例 (6) } & \multicolumn{2}{|c|}{ 症例(7) } \\
\hline & pre & post & pre & post & pre & post & pre & post & pre & post & pre & post & pre & post \\
\hline $\begin{array}{c}\text { RVA } \\
\text { Single }\end{array}$ & $(-)$ & & $(-)$ & $(-)$ & $(-)$ & $(-)$ & $(-)$ & $(-)$ & $(-)$ & $(-)$ & $(-)$ & $(-)$ & $(-)$ & $(-)$ \\
\hline $\begin{array}{c}\text { RVA } \\
\text { Double }\end{array}$ & $(-)$ & & $(-)$ & $(-)$ & $(-)$ & $(-)$ & $(-)$ & $(-)$ & $(-)$ & $\mathrm{VF}$ & $(-)$ & $(-)$ & $(-)$ & VF \\
\hline $\begin{array}{l}\text { RVA } \\
\text { Triple }\end{array}$ & $(-)$ & & $(-)$ & $(-)$ & $(-)$ & $(-)$ & $(-)$ & VF & VF & & VF & VF & $\mathrm{VF}$ & \\
\hline $\begin{array}{l}\text { RVA } \\
\text { Burst }\end{array}$ & $(-)$ & & $(-)$ & $(-)$ & $(-)$ & $(-)$ & $(-)$ & & $(-)$ & & $(-)$ & & $(-)$ & \\
\hline $\begin{array}{l}\text { RVOT } \\
\text { Single }\end{array}$ & $(-)$ & $(-)$ & $(-)$ & $(-)$ & $(-)$ & $(-)$ & $(-)$ & & $(-)$ & $(-)$ & $(-)$ & $(-)$ & $(-)$ & $(-)$ \\
\hline $\begin{array}{l}\text { RVOT } \\
\text { Double }\end{array}$ & $(-)$ & VF & $(-)$ & $\mathrm{VF}$ & VF & VF & $(-)$ & & $(-)$ & & $(-)$ & VF & $(-)$ & $\mathrm{VF}$ \\
\hline $\begin{array}{l}\text { RVOT } \\
\text { Triple }\end{array}$ & VF & & VF & & & & VF & & VF & & VF & & $(-)$ & \\
\hline $\begin{array}{l}\text { RVOT } \\
\text { Burst }\end{array}$ & $(-)$ & & $(-)$ & & $(-)$ & & $(-)$ & & $(-)$ & & $(-)$ & & $(-)$ & \\
\hline
\end{tabular}

全例男性であり, 症例 $1,4 ， 6 ， 704$ 例は無投薬下にて type 1 Brugada型心電図を 呈し, ほかの 3 例ではピルジカイニド負荷試験 $(1 \mathrm{mg} / \mathrm{kg} / 10$ 分)にて coved 型の心電 罒変化をきたした，遅延電位は症例 5 を除いて陽性であった。 
下，HVの軽度延長および心室の ERP延長が見られ ていると報告された.

これらの報告での対象疾患は心室頻拍，上室性頻 拍など様々であるが，VFを呈した症例は含まれて いない.

今回の Brugada症候群患者を対象としたわれわれ の研究では, 電気生理学的諸指標の变化はおおむね 以前の報告と類似した結果が得られたが，HV間隔 の延長が強く認められたことが特徵的であった。

Brugada症候群では，伝導遅延の存在を示唆する報 告があり ${ }^{10)}$, AMDの急性期における $\mathrm{Na}^{+}$チャネル抑 制作用がより強く影響した可能性が考えられた。

\section{2. 体表面心電図の変化}

今回の検討では，体表面心電図に変化をきたした のは1例であった。軽微な変化ではあったが，STが 上昇し，より Brugada心電図を顕在化した可能性が 考えられた。

Brugada症候群の特徵的な心電図の機序として は，RVOT心筋細胞の貫壁性電気勾配での説明が最 も有力視されている ${ }^{11}$. 主として $\mathrm{Na}^{+}$の内向き電流 が減少すると心外膜側心筋の $\mathrm{I}_{\mathrm{to}}$ によるnotchがさら に深くなり，それに続く $\mathrm{Ca}^{2+}$ の内向き電流の変化に より心内膜側心筋との電気勾配が生じ， ST の上昇 がみられると考えられている.

AMD 静注薬投与により Brugada型心電図が顕在 化した以前の報告6では，急性期にみられる $\mathrm{Na}^{+}$チャ ネルの抑制が原因と考察されている.

われわれの研究では，AMD静注薬投与により全 例で $\mathrm{AH}$ 間隔延長を認めており，上記の作用機序に 加えて $\beta$ 遮断作用および直接的な $\mathrm{Ca}^{2+}$ チャネルの抑 制が，Brugada型心電図をより顕在化させた可能性 が考えられた。

\section{3. 心室細動誘発性の変化}

Brugada症候群の特徴的な心電図は，RVOT心筋 細胞の貫壁性電位勾配により生じるとされている. さらに，心外膜側心筋の隣接する細胞間での再分極 のばらつきから phase 2 reentry が生じ，多形性心室 頻拍を生じる。これに伝導遅延が加わることにより
VFに移行するといわれている ${ }^{12}$.

今回の 7 例では AMD 静注薬投与後に施行したプ ログラム刺激によるVFの誘発予防効果は認められ ず，むしろ易誘発性の傾向がみられた. HV 間隔延 長および $\mathrm{AH}$ 間隔延長が認められており， $\mathrm{AMD}$ 静 注薬のもつ $\mathrm{Na}^{+}$チャネル抑制作用, $\beta$ 受容体遮断作 用， $\mathrm{Ca}^{2+}$ チャネル抑制作用の影響が，再分極のばら つきをより顕在化させ，プログラム刺激によりVF が誘発されやすくなる基盤を生じせしめたものと考 えられた。

\section{4. 本研究の問題点}

今回は全例，プロポフォールによる鎮静下に EPS を施行した. Brugada症候群は自律神経の影響を受 けるため，鎮静による影響を考慮しなければならな い.しかし， $\mathrm{AMD}$ 静注薬投与前後のプログラム刺 激はプロポフォール静注薬投与下で行われており， $\mathrm{AMD}$ の効果をみるうえで影響は小さいと考えられた.

$\mathrm{AMD}$ 静注薬は投与期間によりその電気生理学的 効果が変化する ${ }^{13)}$. 今回の検討では投与開始から 1 時間以内に検査が終了しており，それ以降の AMD の効果については評価できていない.

7 例中 5 例で，AMD投与後より簡易なプログラム 刺激にてVFが誘発されるようになった。しかし， EPSによるVFの誘発性に関する改善および悪化の 定義は明確ではない。今回の検討では 3 連期外刺激 から 2 連期外刺激への変化で，必ずしも易誘発性が あるとは断定できなかったＶFの誘発性に対する 改善効果については全例で認められなかった。

EPSにおいてのVFの誘発性が変化したことが, 必ずしも AMD 静注薬の臨床的な薬効を反映してい るかは定かではない.

\section{V. 結 語}

Brugada症候群患者において，AMD 静注薬は， VFの誘発性を改善させる効果をもたないばかりか, 返って増悪させる傾向がみられた。救急の現場では Brugada症候群患者に対して $\mathrm{AMD}$ 静注薬が投与される 可能性があり，今後さらなる検討が必要と考えられた。 


\section{〔文献〕}

1 ) Kudenchuk PJ, Cobb LA, Copass MK, Cummins RO, Doherty AM, Fahrenbruch CE, Hallstorm AP, Murray WA, Olsufka M, Walsh T : Amiodarone for resuscitation after out-of-hospital cardiac arrest due to ventricular fibrillation. N Eng J Med, 1999 ; $341: 871 \sim 878$

2 ) Dorian P, Cass D, Schwartz B, Cooper R, Gelaznikas R, Barr A : Amiodarone as compared with lidocaine for shock-resistant ventricular fibrillation. N Eng J Med, $2002 ; 346: 884 \sim 890$

3 ) Brugada J, Brugada R, Brugada P : Right BundleBranch Block and ST-Segment Elevation in Lead $\mathrm{V}_{1}$ Through $\mathrm{V}_{3}$ : A marker for sudden death in patients without demonstrable structural heart disease. Circulation, 1998 ; $97: 457 \sim 460$

4 ) Antzelevitch C, Brugada P, Borggrefe M, Brugada J, Brugada R, Corrado D, Gussak I, LeMarec H, Nadamanee K, Perez Riera AR, Shimizu W, SchulzeBahr E, Tan H, Wilde A : Brugada syndrome report of the second consensus conference : Endorsed by the Heart Rhythm Society and the European Heart Rhythm Association. Circulation, $2005 ; 111: 659 \sim 670$

5 ) Chalvidan T, Deharo JC, Dieuzaide P, Defaye P, Djiane $P$ : Near fetal electorical storm in a patient equipped with an implantable cardioverter defibrillator for Brugada syndrome. Pacing Clin Electrophysiol, 2000 ; 23 $: 410 \sim 412$

6 ) Paul G, Yusuf S, Sharma S : Unmasking of the Brugada Syndrome Phenotype During the Acute Phase of Amiodarone Infusion. Circulation, 2006 ; 114 : e489 e491

7 ) Kodama I, Kamiya K, Toyama J : Amiodarone : ionic and cellular mechanisms of action of the most promising class III agent. Am J Cardiol, $1999 ; 84$ :
$20 \mathrm{R} \sim 28 \mathrm{R}$

8 ) Ikeda N, Nadamanee K, Kannan R, Singh BN : Electrophysiologic effects of amiodarone : experimental and clinical observation relative to serum and tissue drug concentrations. Am Heart J, $1984 ; 108: 890 \sim 898$

9 ) Wellens HJ, Brugada P, Abdollah H, Dassen WR : A comparison of the electrophysiologic effects of intravenous and oral amiodarone in the same patient. Circulation, $1984 ; 69: 120 \sim 124$

10) Atarashi H, Ogawa S, Harumi K, Sugimoto T, Inoue H, Murayama M, Toyama J, Hayakawa H ; Idiopathic Ventricular Fibrillation Investigators : Three-year follow-up of patients with right bundle branch block and ST segment elevation in the right precordial leads ; Japanese Registry of Brugada Syndrome. Ideopathic Ventricular Fibrillation Investigators. J Am Coll Cardiol, $2001 ; 37: 1916 \sim 1920$

11) Antzelevitch $C:$ The Brugada syndrome : ionic basis and arrhythmia mechanism. J Cardiovasc Electrophysiol, $2001 ; 12: 268 \sim 272$

12) Aiba T, Shimizu W, Hidaka I, Uemura K, Noda T, Zheng C, Kamiya A, Inagaki M, Sugimachi M, Sunagawa K : Cellular basis for trigger and maintenance of ventricular fibrillation in the Brugada syndrome model : high-resolution optical mapping study. J AM Coll Cardiol, 2006 ; 47 : 2074 2085

13) Hohnloser SH, Meinertz T, Dammbacher T, Steiert K, Jähnchen E, Zehender M, Fraedrich G, Just H : Electrocardiographic and antiarrythmic effects of intravenous amiodarone : results of a prospective, placebo-controlled study. Am Heart J, 1991; 121 : $89 \sim 95$ 


\section{Effect of Intravenous Amiodarone on inducibility of Ventricular Fibrillation in patients with Brugada syndrome}

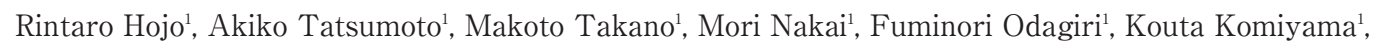
Takao Yuba', Shinichiro Otuka ${ }^{1}$, Hirotaka Komatsu', Yasuhiro Tanabe', Yuka Mizusawa', Seiji Fukamizu',

Tamotsu Tejima', Harumizu Sakurada', Mitsuhiro Nishizaki', Masayasu Hiraoka ${ }^{3}$

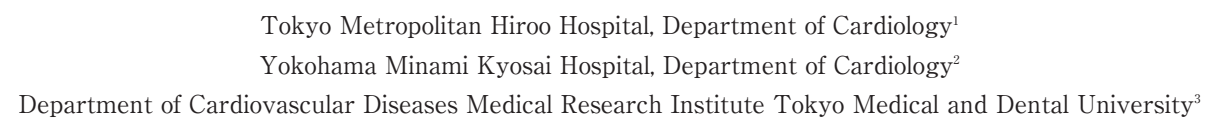

Background : Since 2007, intravenous administration of amiodarone has been approved in Japan. However, the effect of amiodarone infusion for ventricular fibrillation (VF) in patients with Brugada syndrome has not been evaluated yet.

Objectives: The aim of this study is to evaluate how amiodarone infusion affects VF inducibility in patients with Brugada syndrome during electrophysiological study.

Methods : Seven patients (46.6 \pm 5.3 years old, all male) with either spontaneous or pilsicainide-provoked type 1 Brugada ECG underwent electrophysiologic studies for their risk stratification of life-threatening arrhythmias. After amiodarone infusion, VF inducibility was reevaluated.

Results : The AH interval $(97.9 \pm 12.2 \mathrm{msec}$ versus $118.6 \pm 16.1 \mathrm{msec} \mathrm{p}$ value $=0.0008)$ and the HV interval $(47.1 \pm 7.6 \mathrm{msec}$, versus $53.7 \pm 8.9 \mathrm{msec} p$ value $=0.012)$ were significantly prolonged after AMD infusion.

In all patients, $\mathrm{VF}$ was induced by programmed stimulation from right ventricular apex or outflow tract before AMD administration. After AMD administration, VF was induced by a simpler stimulation procedure in five patients.

Conclusion : Amiodarone infusion did not suppress VF inducibility in patients with Brugada syndrome.

Key Words : Brugada syndrome, amiodarone, Electrophysiological Study 